\title{
Determination of Rubraxanthone in the Latex of Asam Kandis (Garcinia cowa Roxb) by Reverse Phase High Performance Liquid Chromatography.
}

\author{
Dachriyanus*, Nova Susanti Asjar, Meri Susanti
}

\section{Dachriyanus*, Nova Susanti Asjar, Meri Susanti \\ Department of Andalas University, Kampus Limau Manis, Padang, West \\ Sumatra, Indonesia \\ Correspondence \\ Dachriyanus}

Faculty of Pharmacy, Andalas University, Kampus Limau Manis, Padang, West Sumatra, Indonesia, 25163

Phone: +628126703735

E-mail: dachriyanus@ffarmasi.unand. ac.id

\section{History}

- Submission Date: 19-12-2016;

- Review completed: 05-01-2017;

- Accepted Date: 06-01-2017.

\section{DOI : 10.5530/pj.2017.2.50}

\section{Article Available online}

http://www.phcogj.com/v9/i2

\section{Copyright}

(C) 2017 Phcog.Net. This is an openaccess article distributed under the terms of the Creative Commons Attribution 4.0 International license.

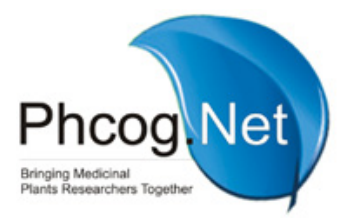

\begin{abstract}
Context: Rubraxanthone is a major compound found in Garcinia cowa Roxb which has various biological activities. This compound is likely to be responsible for the pharmacological activities of this plant. The latex of this plant was one of the source of this compound. To prevent counterfeiting, it is essential to develop a method of analysis to determine the levels of these compounds in the latex of G. cowa. Aims: To develop and validated a reverse phase-high performance liquid chromatography (RP-HPLC) technique for determination of rubraxanthone in the latex of G. cowa. Settings and Design: RP-HPLC analysis. Methods and Material: The sample was powdered and dissolve in methanol and then subjected to Reverse Phase High Performace Liquid Chromatoraphy (RP-HPLC). Separation was carried out in a reversed-phase column Shimadzu Shimp-pack VP-ODS (4.6 x $250 \mathrm{~mm}$ ). The elution was performed with isocratic solvent using formic acid $0.4 \% \mathrm{v} / \mathrm{v}$ in methanol (15:85) with a flow rate $1 \mathrm{ml} /$ minute. The solvents used for the mobile phase were filtered through membrane filter $(0.45 \mathrm{~mm}$ pore size) and degassed before use. Total running time was 20 minutes and the sample injection volume of injection was $20 \mathrm{ml}$. While the wavelength of the UV-VIS detector was set at $243.2 \mathrm{~nm}$. Results: The detection and the quantitation limits of rubraxanthone were $1.119 \mathrm{mg} / \mathrm{mL}$ and $3.731 \mu \mathrm{g} / \mathrm{mL}$, respectively. A regression analysis was performed, with the observation of good linearity $(r=0.998)$. The values obtained for precision and accuracy determination are in agreement with $\mathrm{ICH}$ guidelines. It was found that rubraxanthone in dichloromethane extract of latex G. cowa was $56.56 \%$. Conclusions: The results demonstrated that the developed method is a reliable HPLC technique for determination of rubraxanthone in the latex of $G$. cowa.
\end{abstract}

Key words: Latex of Garcinia cowa Roxb, Rubraxanthone, RP-HPLC, Standarization, Counterfeiting, Isocratic method.

Key Messages: The developed RP-HPLC analysis was found to be reliable method for determination of rubraxanthone in the latex of G. cowa. It was found that concentration of rubraxanthone in dichloromethane extract of the latex was $56.56 \%$.

\section{INTRODUCTION}

Garcinia is a medicinal plant that belongs to the family guttiferae which has been widely used and traded by the Asian community as a traditional medicine to treat various diseases such as diarrhea, skin infections, wounds and as an anti-septic. One of the plants of this family which has been widely used as a traditional medicine is Garcina cowa. ${ }^{1}$

Various components of G. cowa have been used in ancient medication. The bark, latex and root have been used as an antipyretic agent, while fruit and leaves have been used as an expectorant, for indigestion and improvement of blood circulation. ${ }^{1}$ The extract of this plant was reported to have various biological activity such as cytotoxicity, ${ }^{2-4}$ antiinflamatory. ${ }^{2}$

Rubraxanthone (Figure 1) has been isolated as major component of the stem bark of G. cowa. ${ }^{5,6,7}$ This compound has antimicrobial ${ }^{8}$ and antioxidant activity. ${ }^{9}$ It also has anticancer activity against MCF-7, DU-145 and $\mathrm{H}-460^{6}$ as well as can reduce levels of total cholesterol and triglyceride levels in the blood of male rats. ${ }^{10}$ This compound was also reported had anti inflammatory ${ }^{11}$ and anti platelet activity. ${ }^{12}$

The latex of this plant has been used for traditional medicine for centuries and also was one of the source of rubraxanthone. In order to maintain the quality and the quality and o prevent counterfeiting, it is essential to develop a method of analysis to determine the levels of these compounds in the latex of G.cowa. The aim of this study was to develop of RPHPLC method qualitative analysis and to quantify the amount of rubraxanthone in the latex of G. cowa. This system is the first time validated HPLC method has been established for quantitative and qualitative analysis of rubraxanthone in the latex of G. cowa. Determining the amount of rubraxanthone in the latex of $G$. cowa has not been reported before.

\section{MATERIALS AND METHODS}

\section{Chemicals}

Standard rubraxanthone was isolated from G. cowa. ${ }^{6}$ Pure isolated rubraxanthone was used as the external 
standards. All reagents and solvents were analytical and HPLC grades (Merck), except formic acid. High purity bidestilated water was obtained from Otsuka Pharmaceutical Company. The mobile phase was filtered through membrane filter $(0.45 \mu \mathrm{m}$ pore size $)$ degassed before use.

\section{Instrumentation condition}

HPLC method was performed on a Shimadzu (Kyoto, Japan) liquid Chromatograph system, equipped with a model LC-20 AD pump, UVVisSPD M-20A Diode detector. Separation was carried out in a reversed-phase column Shimadzu .Shimp-pack VP-ODS (4.6 x 250mm). The elution was performed with isocratic solvent using formic acid 0.4 $\% \mathrm{v} / \mathrm{v}$ in methanol $(15: 85)$ with a flow rate $1 \mathrm{ml} /$ minute. The solvents used for the mobile phase were filtered through membrane filter $(0.45$ $\mathrm{mm}$ pore size) and degassed before use. Total running time was 20 minutes and the sample injection volume of injection was $20 \mathrm{ml}$. While the wavelength of the UV-VIS detector was set at $243.2 \mathrm{~nm}$. The compound was quantified using CLASS VP

\section{Plant material}

The latex of G. cowa was collected at palupuah, Agam, West Sumatra in March 2016. The latex ( $250 \mathrm{~g})$ was dried in the oven at $50^{\circ} \mathrm{C}$ for 72 hours. The dried latex was grinded to become a powder.

Preparation of standard solutions and sample solutions

A stock solution of rubraxanthone reference standard was ready by dissolving an accurately weighed $10.1 \mathrm{mg}$ of rubraxanthone in $10 \mathrm{~mL}$ of methanol in a volumetric flask. The standard solution was diluted to obtain final concentrations at $10.1 \mu \mathrm{g} / \mathrm{mL}, 15.15 \mu \mathrm{g} / \mathrm{mL}, 20.2 \mu \mathrm{g} / \mathrm{mL}, 25.25$ $\mu \mathrm{g} / \mathrm{mL}$ and $30.3 \mu \mathrm{g} / \mathrm{mL}$ with methanol.

$10.9 \mathrm{~g}$ dichloromethane soluble extract of the dried latex was dissolved in $100 \mathrm{~mL}$ methanol in a volumetric flask. Prior to analysis, the solutions were filtered through $0.45 \mu \mathrm{m}$ membrane filters.

\section{Quantitative analysis of rubraxanthone content}

Analysis was carried out by HPLC under the same condition as the proposed method. Rubraxanthone in the extract was calculated using its calibration curve with regarding to the dilution factor. The content of rubraxanthone in the extract was expressed as gram per 100g of the extract. Each experiment was carried out in triplicate.

\section{Validation of the method}

Validation of the analytical method was done according to the International Conference on Harmonization guideline. ${ }^{13,14}$ The method was validated for linearity, precision, and accuracy, limit of detection (LOD) and limit of quantitation (LOQ).

\section{Linearity}

Linearity was determined by using rubraxanthone standard solution to give concentration of $10.1 \mu \mathrm{g} / \mathrm{mL}, 15.15 \mu \mathrm{g} / \mathrm{mL}, 20.2 \mu \mathrm{g} / \mathrm{mL}, 25.25 \mu \mathrm{g} /$ $\mathrm{mL}$ and $30.3 \mu \mathrm{g} / \mathrm{mL}$ in methanol, each of the standard solution was prepared $(n=3)$. A calibration curve was made by plotting the area obtained from the analysis of the concentration of the standard solution using the linear regression equation. Linearity is determined by the price of coefficient correlation $(r)$.

\section{Pressision and acuration}

Precision was determined by analyzing three different concentrations $(10.1 ; 20.2 ; 30.3 \mathrm{mg} / \mathrm{mL})$ of standard solution rubraxanthon on the same day as much as 3 times reinjection for intraday precision and at three different concentrations $(10.1 ; 20.2 ; 30.3 \mathrm{mg} / \mathrm{mL})$ each reinjection 3 times per day for 3 days for interday precision. Intra- and inter-day assay precisions were determined as relative standard deviation (RSD). Intra- day precision (repeatability) involved three replicates per day and inter-day (intermediate) precision were performed on three separate days. Accuracy views of proximity compared with actual results.

\section{Limit of detection (LOD) and limit of quantification (LOQ)}

According to ICH $1995,{ }^{13}$ technical needs for the registration of prescribe drugs for human use recommendations, the approach based on $\mathrm{SD}$ of the response and also the slope was used for determining the detection and quantitation limits. The limits of detection and quantitation can be calculated statistically by linear regression line of the calibration curve. The measurement value will be equal to the value of $b$ in the linear equation $\mathrm{y}=\mathrm{a}+\mathrm{bx}$

$\mathrm{LOD}=3 \times$ o $/ \mathrm{S}$

$\mathrm{LOQ}=10 \mathrm{x}$ ơ $/ \mathrm{S}$

Where: $\sigma=$ standard deviation $; \mathrm{S}=$ slope or linear line direction

Recovery study

The accuracy of this method was tested by performing recovery studies at three levels of standard rubraxanthone were added to the sample. Three different concentrations $(10.1 ; 20.2 ; 30.3 \mathrm{mg} / \mathrm{mL})$ of standard solution are added to the sample solution $(21.8 \mathrm{mg} / \mathrm{mL})$, which has been known to rubraxanthone levels in it and analyzed using HPLC method. Do three repetitions for each level of concentration. Then calculate the return of the acquisition.

\section{Determination of concentration of rubraxanthon by HPLC method}

The dichloromethane extract of dried latex at a concentration of 21.8 $\mathrm{mg} / \mathrm{mL}$ was injected into $20 \mathrm{~mL}$ HPLC instrument with the same conditions as that obtained when testing the suitability of the system with three times repetition. Rubraxanthon levels in the extract was calculated using a calibration curve which has been obtained previously.

\section{RESULTS}

A reverse phase HPLC method was developed keeping in mind the system suitability parameters i. e. tailing factor $(\mathrm{T})$, number of theoretical plates $(\mathrm{N})$, runtime and the cost effectiveness (Table 1$)$. The most optimal mobile phase for analysis rubraxanthone was methanol: $0.4 \%$ formic acid (85:15) with a flow rate of $1 \mathrm{~mL} / \mathrm{min}$. The optimized method developed resulted in the elution of rubraxanthone at 15.417. Figure 2 showed chromatogram of dichloromethane extract of the latex of $G$. cowa. The total run time is 20 minutes.

The described method was validated according to the ICH guidelines. ${ }^{9}$ The following validation characteristics were evaluated: linearity, precision, accuracy and the limits of detection and quantification (LOD and LOQ).

The linearity study by using a standard solution concentration of 5 series rubraxanthonegave regression equation $\mathrm{y}=\mathrm{x} 103214-527433$ and the value of the correlation coefficient $(\mathrm{R})=0.998$ [Table 2].

Based on the standard curve equation LOD and LOQ values obtained on the analytical methods used amounted to $1.119 \mathrm{mg} / \mathrm{mL}$ and $3.731 \mathrm{mg}$ / $\mathrm{mL}$ [Table 3].

The repeatability and intermediate precision were $3.03 \%$ and $2.84 \%$, respectively. The mean of peak area, rubraxanthone content and the relative standard deviation are reported in Table 4.

The accuracy of the method was determined by adding known amount of rubraxanthone standard in known latex of G. cowa extract at three levels of concentration. The mean values of the percentage analytical re- 
Table 1: System suitability data of the proposed method

$\begin{array}{cc}\text { Parameters } & \text { Rubraxanthone } \\ \text { Retention time (min) } & 15.417 \\ \text { Resolution } & 1.558 \\ \text { Number of theoretical plates (N) } & 441.772 \\ \text { Tailing factor (T) } & 1.454 \\ \text { Height Equivalent to a Theoretical Plate (HETP) } & 0.566 \\ { }^{*} \text { Means of three injections } & \end{array}$

Table 2: Linearity of Rubraxanthone in the RP-HPLC analysis

\begin{tabular}{|lcccc}
\hline & $\begin{array}{c}\text { Concentration } \\
\text { range }(\mu \mathrm{g} / \mathrm{mL})\end{array}$ & Slope & Intercept & r \\
\hline Rubraxanthone & $10.1-30.3$ & 103214 & 527433 & 0.998 \\
\hline
\end{tabular}

Table 3: Limit of Detection (LOD) and Limit of Quantification (LOQ)

\begin{tabular}{|lccccc} 
& $\begin{array}{c}\text { Concentration } \\
\text { range } \\
(\mu \mathrm{g} / \mathrm{mL})\end{array}$ & Slope & $\begin{array}{c}\text { Standard } \\
\text { deviation } \\
\text { of } y-\end{array}$ & $\begin{array}{c}\text { LOD } \\
(\mu \mathrm{g} / \\
\mathrm{mL})\end{array}$ & $\begin{array}{c}\mathrm{LOQ} \\
(\mu \mathrm{g} / \\
\mathrm{mL})\end{array}$ \\
\hline Rubraxanthone & $10.1-30.3$ & 103214 & 38509,350 & 1,119 & 3,731 \\
\hline
\end{tabular}

Table 4: Precision of HPLC method for quantitation of rubraxanthone in the latex of G. cowa Roxb

\begin{tabular}{|c|c|c|c|c|}
\hline & Peak area & $\begin{array}{l}\text { RSD } \\
(\%)\end{array}$ & $\begin{array}{l}\text { Rubraxanthone ( } \mu \mathrm{g} / \\
\mathrm{mL})\end{array}$ & $\begin{array}{l}\text { RSD } \\
(\%)\end{array}$ \\
\hline Repeatability $^{\mathrm{a}}$ & $1902049.67 \pm 0.425$ & 1.416 & 29.997 & 1.402 \\
\hline $\begin{array}{l}\text { Intermediate } \\
\text { precision }\end{array}$ & $2332417.78 \pm 0.590$ & 1.926 & 30.610 & 1.947 \\
\hline
\end{tabular}

Table 5: Accuracy of the HPLC method

\begin{tabular}{|cccc} 
& $\begin{array}{c}\text { Rubraxanthone } \\
\text { added }(\mu \mathrm{g} / \mathrm{mL})\end{array}$ & $\begin{array}{c}\text { Rubraxanthone found } \\
(\mu \mathrm{g} / \mathrm{mL})\end{array}$ & Recovery (\%) \\
\hline A & 5.05 & 4.78 & 94.66 \\
B & 10.10 & 9.65 & 95.51 \\
C & 15.15 & 14.71 & 97.12 \\
\hline
\end{tabular}

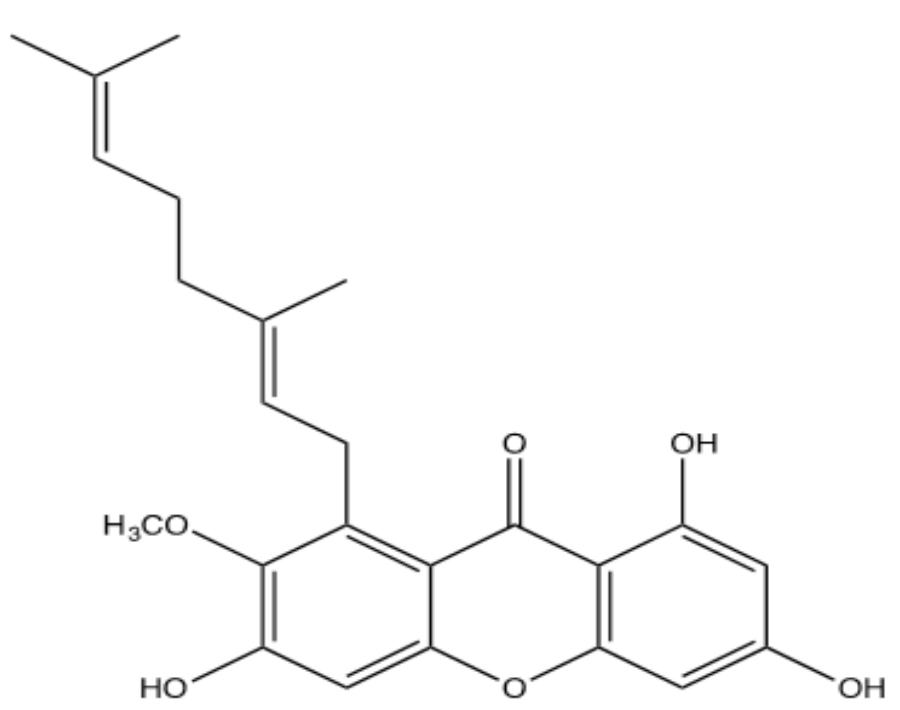

Figure 1: Rubraxanthone

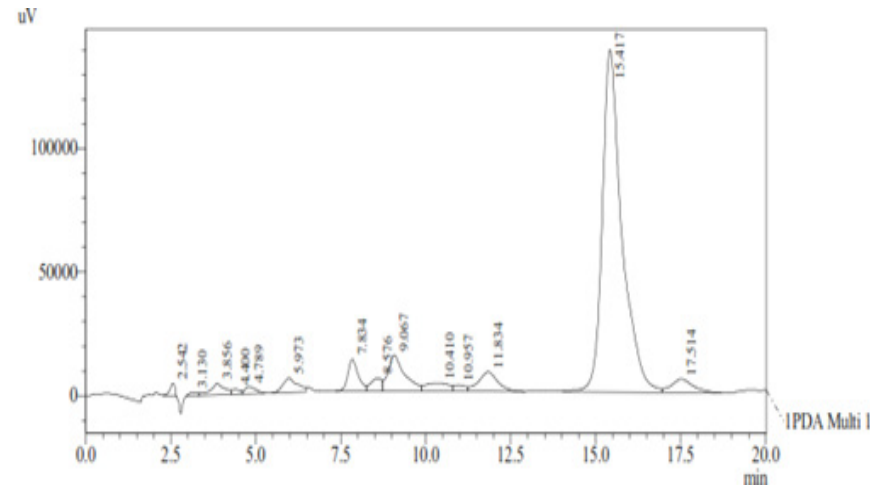

Figure 2: Typical chromatogram of dichloromethane extract of the latex of G. cowa with mobile phase methanol: formic acid $0,4 \%(85: 15)$ with flow rate $1 \mathrm{~mL} / \mathrm{min}$.

coveries for the concentration of $5.05,10.10$ and $15.15 \mu \mathrm{g} / \mathrm{mL}$ of rubraxanthone were $94.66 \%, 95.51 \%$ and $97.12 \%$, respectively Table 5 .

\section{DISCUSSION}

HPLC method with isocratic elution was developed for the quantification of rubraxanthone in soluble dichloromethane extracts of latex of $G$ cowa. The chromatographic analysis developed for quantitative determination of this xanthone was validated according to $\mathrm{ICH}$ guidelines to obtain reproducible analyses with high degree of accuracy and precision. ${ }^{13}$

A regression analysis was performed, with the observation of good linearity in a wide concentration range. The values obtained for precision and accuracy determination are in agreement with $\mathrm{ICH}$ guidelines, ${ }^{13}$ which indicated that the chromatographic conditions used are reliable to quantify the xanthone. From the test results obtained by the average level of rubraxanthon in plant extract G.cowa is $56.56 \%$.

\section{CONCLUSION}

Concentration of rubraxanthone in dichloromethane extract of the latex of kandis acid G. cowa was $56.56 \%$. This exudate can be used as source of rubraxanthone.

\section{ACKNOWLEDGMENTS}

This research was funded by Faculty of Pharmacy, Andalas University no 23/UN.16/HKRGB/LPPM/2016.

\section{CONFLICT OF INTERESTS}

The authors have no conflict of interest

\section{ABBREVIATIONS USED}

PLC: performance liquid chromatography; ICH: International Conference on Harmonization; LOD: limit of detection; LOQ: limit of quantitation; RSD: relative standard deviation; HETP: Height Equivalent to a Theoretical Plate; RP-HPLC: Reverse Phase High Performance Liquid Chromatography; ICH: International Conference on Harmonization; LOD: limit of detection; LOQ: limit of quantitation; RSD: relative standard deviation; HETP: Height Equivalent to a Theoretical Plate.

\section{REFERENCES}

1. Ritthiwigrom T, Laphookhieo S, Pyne SG. Chemical constituents and biological activities of Garcinia cowa Roxb; Maejo Int J Sci and Techology. 2013;7(02):212 31.

2. Jabit ML, Wahyuni FS, Khalid R, Israf DA, Shaari K, Lajis NH, Stanslas J. Cytotoxic and nitric oxide inhibitory activities of methanol extracts of garcinia species. Pharm Biol. 2009;47(11):1019-26. https://doi.org/10.3109/13880200902973787.

3. Wahyuni FS, Triastuti DH, Arifin H. Cytotoxicity Study of Ethanol Extract of the 
Leaves of Asam Kandis (Garcinia cowa Roxb.) on T47D Breast Cancer Cell line. Pharmacogn J. 2015;7(6):369-71 https://doi.org/10.5530/pj.2015.6.9.

4. Husni E, Nahari F, Wirasti Y, Wahyuni FS, Dachriyanus. Cytotoxicity study of ethanol extract of the stem bark of asam kandis (Garcinia cowa Roxb.) on T47D breast cancer cell line. Asian Pac J Trop Biomed. 2015;5(3):249-52 https://doi. org/10.1016/S2221-1691(15)30013-7.

5. Wahyuni FS, Byrne LT, Dachriyanus, Dianita R, Jubahar J, Lajis NH, Sargent MV. A new ring-reduced tetraprenyltoluquinone and a prenylated xanthone from Garcinia cowa. Aust J Chem. 2004;57:223-6. https://doi.org/10.1071/CH03175.

6. Wahyuni FS, Shaari K, Stanslas J, Lajis NH, Dachriyanus. Cytotoxic xanthones from the stem bark of Garcinia cowa Roxb. J Chem Pharm Res. 2015;7(1):22736.

7. Susanti M, Putra DP, Wahyuni FS, Dachriyanus. Penentuan Kadar Rubraxanton pada Ekstrak Kulit Batang Garcinia spp. Jurnal Farmasi Indonesia. 2013;6(3):15965

8. Lee H, Chan H. 1,3,6-trihydroxy-7-mehoxy-8-(3,7-dimethyl-2,6-octadienyl) xanthone from Garcinia cowa. Phytochem. 1997;16:20038-40.
9. Dachriyanus, Dianita R, Jubahar J. Isolasi senyawa antioksidan dari kulit batang Garcinia cowa Roxb; Jurnal Matematika dan Pengetahuan Alam. 2003:12(2):6772.

10. Dachriyanus, Sartika L, Kesuma M, Mukhtar MH, Efek Senyawa Rubraxanthon Terhadap Kadar Kolesterol Total, Trigliserida, HDL dan LDL Dalam Darah Mencit Putih Jantan. J Sains Tek. Far. 2006;11(1):12-5.

11. Wahyuni FS, Ali DAI, Lajis NH, Dachriyanus Anti-inflammatory Activity of Isolated Compounds from the Stem Bark of Garcinia cowa Roxb. Pharmacogn J. 2017;9(1):55-7 https://doi.org/10.5530/pj.2017.1.10.

12. Jantan I, Pisar M, Idris MS, Taher M, Ali RM. In Vitro Inhibitory Effect of Rubraxanthone Isolated from Garcinia parvifolia on Platelet Activating Factor Receptor Binding. Planta Med. 2002;68:1133-4. https://doi.org/10.1055/s-2002-36343.

13. International conference on harmonization of note for guidance on validation of analytical procedures: text and methodology, Step 5 of the ICH Process; 1995.

14. Food and Drug Administrasion. Guidance for Industry "Bioanalytical Method Validation." U.S. Department of Health and Human Services, 2001

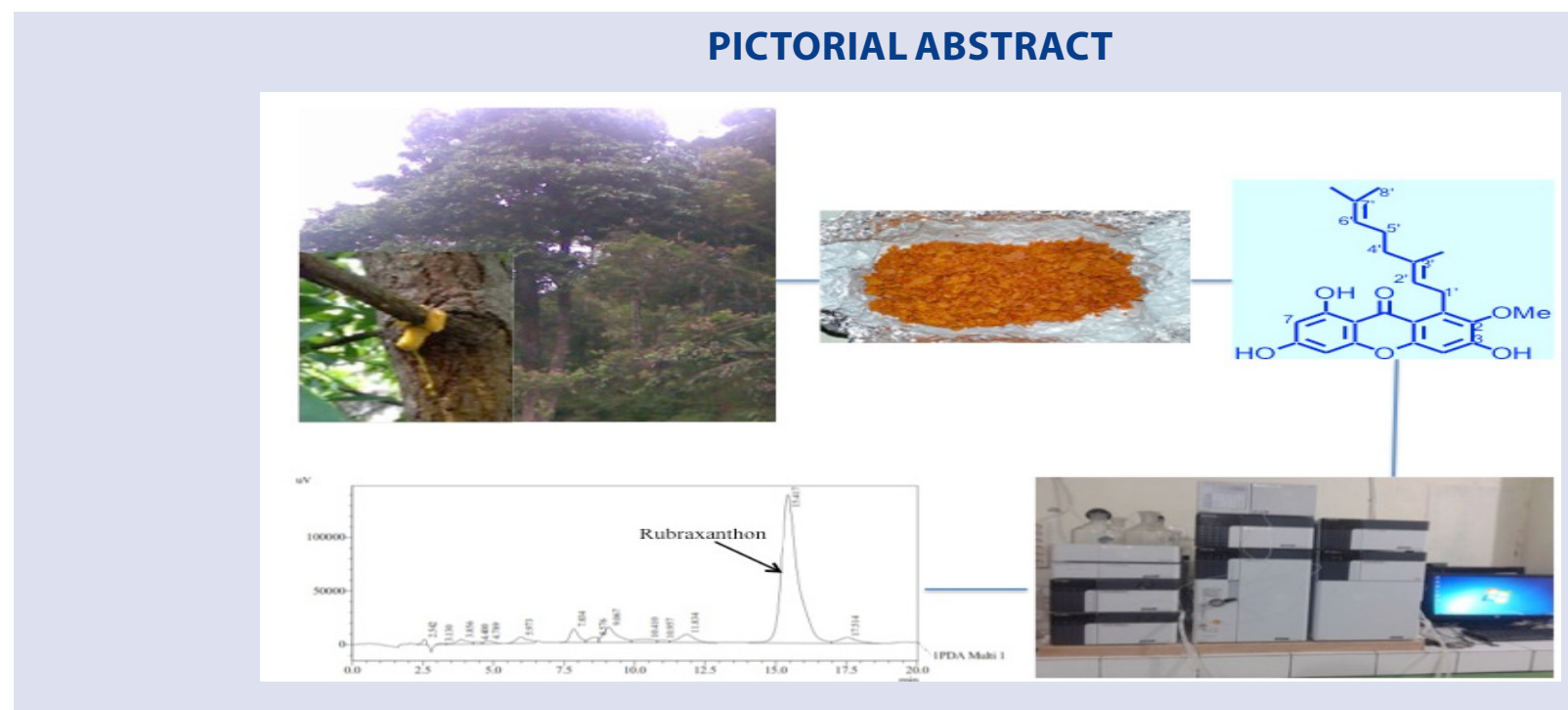

ABOUT AUTHORS

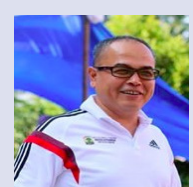

Dachriyanus: Got his undergraduate degrees from Andalas University in 1991 and finished my PhD from University of Western Australia in 1999. He is positioned as Professor of Pharmacy at Faculty of Pharmacy, Andalas University. His research is in chemical and biological activity studies of Sumatran Plants especially Genus Garcinia and Rhodomyrtus tomentosa.

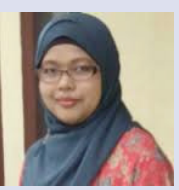

Meri Susanti: Is PhD student of from Andalas University. She is positioned as young lecturer at Faculty of Pharmacy, Andalas University. Her research is in standardization of Sumatran medicinal plants especially Genus Garcinia.

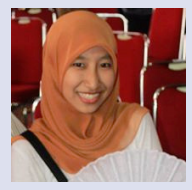

Nova Susanti Asjar: Was undergraduate student of faculty of Pharmacy Andalas University. Her research is determination of concentration of rubraxanthone in the latex of Garcinia cowa.

Cite this Article: Dachriyanus, Asjar NS, Susanti M. Determination of Rubraxanthone in the Latex of Asam Kandis (Garcinia cowa Roxb) by Reverse Phase High Performance Liquid Chromatography. Pharmacogn J. 2017;9(2):288-91. 